SPACE

\section{Same Old Story}

LAST week's performance by the European nations at the European Space Conference ran true to form with nobody agreeing with anybody else. As a result no decisions were taken, the ministers returned home to think things over, and the circus will get under way again on July 31 .

The postponing of decisions until then makes timing for the Spacelab programme rather tight. The European Space Research Organization has until August 15 to let NASA know whether or not it is going to participate in the post-Apollo programme by building Spacelab. Originally the ESRO council was to formally take its decision on July 31, after last week's space conference, but now that the ESC is meeting on that day, ESRO has put back its meeting to August 1. But any failure to agree on July 31 must seriously jeopardize the possibility of Europe meeting the August 15 deadline.

Last week's problems were merely a continuation of the old troubles. Britain does not want to build launchers, but France does; Germany wants to build Spacelab, but not a maritime satellite, which is currently Britain's favourite project. The situation was further complicated by several of the other European nations sending their ministers to the eleven member conference without clear mandates on what projects to support. Hopefully everyone will have decided where they stand by the end of the month.

Meanwhile ESRO has run into a headwind with its plans for Aerosat. ESRO was hoping shortly to initial a memorandum of understanding with the United States Administration which would have set up a joint Aeronautical Satellite Evaluation Programme between the European nations, the United States and Canada. The programme would have examined the possibilities of controlling air traffic by satellite-a problem that is becoming increasingly urgent as the number of flights over the Atlantic and Pacific mount ( 800 flights a day are projected for the north Atlantic by 1980). The airlines in the United States, however, are having doubts about the programme-possibly because they are not too certain they want to pay if it is finally decided to go ahead. As a result, although no official word has come from the USA, it has become plain that the United States Administration may not be able to sign the agreement as it stands. ESRO has therefore postponed the choice of an industrial partner in the United States. If all had gone well, ESRO would have chosen between five United States aerospace companies who were to have been full partners in the development of the space segment of the aerospace programme-the building of the satellites and associated launch and control facilities.

So worried is ESRO by the prospect of the United States not signing that it has decided to examine the possibilities open to it if the United States does back out. Cooperation with Canada, and later Japan and Australia, is still very much on the cards, and ESRO is to examine the possibilities of using an adapted version of the Orbital Test Satellite as the basis for an aeronautical satellite. Clearly the intention is to put some pressure on the United States Administration from the European end, to balance the pressure that the airlines are currently exerting.

\section{POLAND}

\section{Ten Year Plans}

from a Correspondent

The Second Polish Scientific Congress, which met recently in Warsaw, had as its theme "Science in the service of the community" and was devoted, essentially, to the planning of research and expansion for the next decade or more. Held, auspiciously, in a year which commemorates not only the 500th Aniversary of the birth of Copernicus, but also the bi-centenary of the Polish Educational Commission and the centenary of the foundation (in Cracow) of the Polish Academy of Sciences, the Conference was attended by more than 2,000 delegates, some 900 of whom came from the Warsaw area.

Outlining the development of Polish science since the first congress, twenty years ago, the President of the Polish Academy of Sciences, Academician Wlodzimierz Trzebiatowski noted that Poland now has more than 350 scientific research institutes, design bureaux and laboratories, and that the number of senior qualified personnel is now 260,000 . He placed special emphasis, in accordance with current COMECON policy, on the role of scientists and scientific institutions in "accelerating scientific and technological progress".

Among the individual speeches, outlining plans for the coming decade, Professor Dionizy Smoleński, vicepresident of the Academy, indicated that in the exact sciences, a basis of research "integrally linked" with the over-all economic development of the country has now been established, and that special emphasis should be placed on developing such fields as cryoelectronics, plasma physics, laser technology and information processing techniques. For the biological sciences, Professor Bohdan Dobrański stressed the need for increased concentration on molecular, environmental and evolutionary biology.

\section{REACTORS Gas Breeder Moves}

REACTOR designers in both Europe and the United States are pushing ahead with plans for a gas-cooled fast breeder reactor (GFBR). At a meeting of interested parties in London last week, convened by the British Nuclear Forum, the view was expressed that the better breeding capabilities of the GFBR make it particularly attractive when linked with the High Temperature Reactor (HTR) and in discussions it was generally accepted that the GFBR also offers a high degree of safety.

In Europe the running as far as GFBRs are concerned has been made by the Nuclear Energy Agency of the Organization for Economic Cooperation and Development and by the Gas Breeder Reactor Association (GBRA), which represents those parts of industry with an interest in GFBRs. In the long term the GBRA aims to see the construction of a GFBR demonstration plant started in Europe before the end of the decade. So far the GBRA has spent $£ 0.75$ million through its study group in Brussels since it was set up in 1969. The NEA collaborative programme, on the other hand, involves the coordination of $£ 5$ million of work in government laboratories around Europe. In addition Kraftwerk Union is working independently on the GFBR with government aid.

The prime mover in the United States is Gulf General Atomic, which sees the GFBR as a natural partner for its HTRs. Dr P. Fortescue of Gulf spoke of the "symbiosis of fast and thermal reactors" and of a situation in which a fast breeder reactor would act as a fuel factory for an HTR, independent of external means of enrichment and supplying such materials as uranium-233. The fact that a helium coolant does not much modify the spectrum of neutrons within a reactor, by contrast with liquid sodium, makes the GFBR a better breeder than sodium-cooled reactors like the one at Dounreay and thus a more suitable partner for the HTR on economic grounds. The HTR has other advantages of its own, of course, in that it can produce process heat at a temperature of interest, for example, to steelmakers and the chemical industry. Gulf, supported by many interested utilities, has sunk about $£ 6$ million into the GFBR and although not committed to a particular year for starting on a demonstration plant it has a thirteenyear schedule drawn up for a $300 \mathrm{MW}$ reactor system. It now seems possible that a GFBR will be chosen to follow the Westinghouse sodium-cooled reactor as the second nationally founded demonstration plant in the USA. 